\title{
Kartini's Teacher Concept and Principles in Letters of a Javanese Princess
}

\author{
Benedikta Atika Putri \& Maria Vincentia Eka Mulatsih \\ benedikta.atika09@gmail.com,mv_ika@usd.ac.id \\ English Language Education Study Program, Sanata Dharma University
}

\begin{abstract}
Letters of a Javanese Princess is a translated literary work from a compilation of letters entitled Door Duisternis tot Licht (Out of Dark Comes Light). This work was written by Raden Adjeng Kartini and generally portrayed women's emancipation and education. As a root of women's education, tracing the history of the detailed concept of Indonesian education from this work means knowing the original concept of a good teacher and some teaching principles. Thus, Kartini's teacher concept and principles were analysed in this article. Based on the analysis, the first finding shows that there are two teaching principles that Kartini has. The first is that teaching should include moral and intellectual aspects. According to Kartini, education does not only mean educating the brain but also having concern about morality and spirituality. The second is that the material of teaching should be suitable for the need of the era and students. The second finding shows that there are three points to be a good teacher: a teacher should get basic education for the profession, a teacher should be an excellent example for students, and a teacher should teach opened-mindedness, love, rights, and justice. Those important things are aimed to raise education for our nation.
\end{abstract}

Article

information

Keywords: teacher; principles; Kartini

DOI: 10.24071/joll.v20i2.2364

Available at https://e-journal.usd.ac.id/index.php/JOLL/index

This work is licensed under a Creative Commons Attribute-ShareAlike 4.0 International License

\section{Introduction}

Kartini, in Letters of a Javanese Princess, tried to deliver and shared her thought on what Javanese girls need. Teaching in a school was proof of Kartini's action to change the old concept of Javanese girls. During the teaching time, she also showed and stated her perspective about an excellent teacher and some principles of teaching that were suitable for students. This study is inspired by Korthagen et al. (2006), who said that studies about teacher education had been published, but there was a lack of central principles underlying teacher education programs. These central principles can be traced back to some literary works that portray this topic, and one of them is from Kartini's letters.

Through her letters, Kartini tried to prove that education could be the option to build the country. Her letters were compiled in a book entitled Letters of a Javanese Princess. The letters were translated from the Dutch by Agnes Louise Symmers. This book consists of 246 pages and 78 letters which were written by Kartini to her Dutch friends. The letters were written from May 25, 1899 until 
September 7, 1904, or several years before Kartini died. The book was published by The Norton Library New York in 1964. Furthermore, this book has been accepted in the Indonesian Translation Series and sponsored by the United Nations Educational, Scientific and Cultural Organization (UNESCO).

Tracing back the history or tradition from a nation is fundamental to have strong principles in the world of education. Kartini's letters as a literary work can be one of the sources to achieve the original concept of Indonesian education. The analysis of this work provides many significances in the educational field. One of them is to know the spirit of a good teacher's concept or principles.

In line with Kartini's thought, Sularto (2016) underlines the importance of education that can enlighten people's mindsets about human rights. Realizing that education takes an important role in developing humans' qualities, some studies on how to conduct qualified education matter (Jing, et al., 2010; Proctor, 1998; Sulisworo, 2016). Although today's teaching style has many differences from old-style, learning the history and the root of education as the spirit of a nation is considered vital.

By analyzing the teaching principles and good teacher concept, educators, especially in Indonesia, will know the historical idea of teaching and be able to reflect the idea for daily teaching. Therefore, it is essential to discover Kartini's teaching principles and a good teacher concept in her letters entitled Letters of a Javanese Princess.

Based on the background above, there are two research problems formulated as follows:

1. What are Kartini's teaching principles as seen in Letters of a Javanese Princess?

2. What are Kartini's point of views about a good teacher as seen in Letters of a Javanese Princess?

Previous problem formulation has a connection with previous studies that have been conducted by Jing, et al. (2010), Proctor (1998) and Sulisworo (2016). While Jing, et al. shared the importance of social history education in China engineering field and
Proctor rediscovered a tradition that could improve the school, this study focuses more on the spirit of Indonesian education. Another study from Sulisworo (2016) also discussed the contribution of education to build Indonesia. Still, the main principle of education, in this case, the principle of teaching has not been discussed before. Knowing that some researchers from other countries have researched the root of education principles, this study is an effort to do so.

\section{Methodology}

Since the purpose of this study is to dig more deeply into some teaching principles and a good teacher concept of Kartini, the Formalist approach was used to analyze and answer the problems formulated in this study. According to Guerin, et al. (2010) formalist approach is a new critical approach that analyzes the content of literary works.

In conducting the research, document analysis was used as the data analysis technique. According to Bowen (2009), document analysis is an orderly procedure for evaluating and analyzing electronic and printed documents. There were some steps for conducting this research. The first was gathering the data from work by reading and highlighting all parts concerning a good teacher concept and teaching principles. The second was classifying the data into two parts. Then, they were classified again into some parts. The third was analysing the data by relating each datum using the formalist approach. The last step was writing the result of the analysis qualitatively. In addition to those, some theories of the educational role and teaching principles from Bruzzelli, Stookberry, Schussler, Brecaw, Ryan and Bohlin, Setiawan, Tom, Driyakarya, Engku Syafei, Ki Hajar Dewantara, and Petty are used to answer the research questions.

\section{Results and Discussion}

In 1990, Kartini wrote letters to Mevrouw M. C. E. Ovink-Soer. She told her about her dreams. She would open a school for girls of the nobility. She also hoped that she and her 
sister could get the chance to study abroad in Holland;

Our people are not rich in ideals, but an example which speaks, would impress them. They would be impelled to follow it. My sister and I wish to go before and lighten the way; for that reason, we want more than anything else to go to Holland to study. It will be well with us if we can go. Little Mother, help us!

When we come back to Java, we shall open a school for girls of the nobility; if we cannot get the means through our Government, then we will work for it in some other way; ask our friend to subscribe, start a lottery or something." ( $\mathrm{p}$. 66)

At that time, Kartini got new hope and spirit. By writing her letters, she told some teaching principles that she would apply to her class.

\section{Teaching Moral and Intellectual should be Balanced}

Tom (1984) said that "It can be easily argued that teachers have a moral responsibility to influence the development of their students" (as cited in Stooksberry, Schussler, and Bercaw, 2009, p. 727). Connecting to Kartini's statements, Kartini believed that teaching is not only improving the cognitive aspects of students but also giving moral education during the learning activity. She elaborated her idea into her letter to Mevrouv M. C. E. Ovink-Soer in 1990 and Heer E. C. Abendanon on January 27, 1903;

But is an intellectual education everything? To be truly civilized intellectual and moral education must go hand in hand. (p. 65).

It is true that in "our school" (how pleasant that sounds) we want to give more of a moral than an academic education...Let them go to school outside, but give them moral education here with us. We could lead the young hearts through play and help to form the young characters." (p. 213).
Kartini stated the importance of moral education for students. She also showed if she was brave enough to be different. She wrote that she would open a school and educate people even though the government would not support them. In this case, she focused on how to educate Javanese girls to be independent. She wrote her statement in the letter for Heer E. C Abendanon on January 27, 1903;

If it is not erected by Government we would not follow the prescribed paths, and we want the whole idea of our school to be the education of children, not through they were in school, but in a home, as a mother would bring up her own children (p. 213).

Kartini believed that educating people could be done everywhere. As she mentioned, if the government would not support her idea of school, she would still educate children in a home like a mother would bring up her own children. Kartini spread the idea that educating people was not always in schools and classes.

Besides, Driyarkara (1980) stated that everyone should do the law of morality that is already attached when a human was born. Based on the law of morality, a human must give true love and respect other people. In a different letter, Kartini gave more evidence that the result of education was not always the improvement of cognitive aspects but also the forming of the mind and the soul. She mentioned in the letter to Mevrouv Abendanon-Mandri on January 21, 1901;

\section{Education means the forming of the mind and of the soul. I feel that with the education of the mind the task of the teacher is not complete. The duty of forming the character is his; it is not included in the letter of the law, but it is a moral duty (p. 99).}

Through the letters, Kartini expressed that forming the character of students is a moral duty. It was a must for teachers to educate and to construct some good characters of students. Engku Syafei, a pioneer of the development Bumiputera also had the same opinion. He emphasized education in mind 
(intellect), in heart (the sensitivity of human being) and in hand (skills) (as cited in Sularto, 2016, p. 108). Engku Syafei agreed that those things should be in a classroom together with the moral values that the teachers believe. Indeed, this belief supports $\mathrm{Ki}$ Hajar Dewantara's education concept, which says that students must have inner strength and good characters (as cited in Sularto, 2016).

As declared by Petty (2009), there is a hidden curriculum that a good teacher should teach. The curriculum should be applied in a general way. He underlines some materials that teachers should teach using the "Modelling" method. The teacher teaches unconsciously by his/her behavior towards students (p. 21). For example, a teacher who smiles at, talks to, and helps the students of Asian and European origin equally, is teaching the students to respect anyone, regardless of their origins. This theory has a strong connection between the moral education that teachers should teach. At the same time, teachers should be the example or the model of good behavior.

\section{The Teaching Materials Should Match Students' Need and the Issue of the Era}

In this part, Kartini emphasized two things that a teacher should teach as the primary education for students. She thought that hygiene \& sanitation and trade were suitable materials in the era. In Kartini's era, the education of hygiene and sanitation was not good enough. People were going to the river or the beach for bathing and washing clothes. Kartini got the idea about teaching the hygiene and sanitation in her class. She wrote her idea to Mevrouw Van Kol in August 1901;

My sister and I should then be able to work together. And what we are most anxious to have taught in our future schools is hygiene, and the knowledge of sanitation and nursing. Hygiene and nursing should be part of one's education. So many misfortunes could have averted or at least reduced to a minimum, if everyone, men, as well as women, had been taught something of this useful study (p. 116).
The reason why she wanted to give the material about hygiene and nursing was to develop the exceptional qualities of Indonesian. In that era, Javanese people really needed it as basic education.

However, Kartini did not mention how she guided the material into a specific activity. She tried to create a healthy homelike learning environment by mentioning some subjects that might be taught in her class. The ideas were written twice in the letter to Stella Zeehandelaar on May 20, 1901, and October 11,1901 . She mentioned some subjects such as the handiwork, household arts and kindred, wood-carving, painting, and in midwifery.

If fate is propitious we shall open a school in which instruction will be given along broader lines than mere book education; it will include lessons in handiwork, household arts and kindred subject and there will also be classes in wood-carving and painting, and in midwifery (p. 126).

What an ideal school that Institute for Native Young Ladies will be! Science, cooking, housekeeping, handiwork, hygiene and vocational training; all must be there! It is only a dream, but let us dream if it makes us happy (p. 106).

Those subjects might improve students' skills and fulfill students' needs. The materials that Kartini taught were really useful for the students. She would like to create an active and skillful learning activity by introducing the subjects.

Kartini also stated that she would teach students about trade. The only reason why she wanted to teach about the trade was that she did not want to make people, especially girls, powerless. She would enlighten all of the Javanese people so that they would live and be treated as human beings. Kartini delivered her idea about empowering people through the letter to Mevrouv Van Kol in August 1901;

Our work will have twofold aim, first to help to enlighten all our people, and secondly to raise up our sisters, so that they may live and be treated as human beings. To all of you who have sympathy 
for Java, and the Javanese, we send an urgent prayer- help us to realize our ideals; they mean so much to our people and to our sex" (p. 112).

Raise the Javanese woman, educate her heart and her understanding, and you will have splendid workers to cooperate with you in your noble work, your giant's work, the work of civilizing and enlightening a whole nation.

Teach her a trade, so that she will no longer be powerless when her guardians command her to contract a marriage which will inevitably plunge her and whatever children she may have into misery.

The only escape from such condition is for girl herself to learn to be independent ( $\mathrm{p}$. 113).

She wanted to make Javanese people free and independent. At the same time, she had an idea about establishing a homelike learning environment to encourage people to learn. She emphasized her ideas about homelike learning environment through her writing to Heer E. C. Abendanon on January 27, 1903, and Mevrouw Abendanon, July 4, 1903;

It must be like a great home community. Where inmates all love one another and learn from one another, and where the mother is not a mother in name of spirit, the educator of the child's soul and body (p. 213).

The children come here four days in the week, from eight to half past twelve. They study, writing, reading, handiwork and cooking. We teachers do not give lessons in art unless the pupils show a special aptitude for it. Our school must not have the air of a school, or we that of schoolmistresses (p. 223).

As seen in her writings, she avoided the atmosphere of school in general. She didn't want to make the students under pressure and get the schoolmistresses.

Kartini also mentioned some criteria or concepts of a good teacher. She also believed that a teacher was not always a person who taught students in the class. She said that women had to know how to be a good teacher. It was because they should teach their children in the future. Kartini wrote the letter to M. C. E. Ovink-Soer in 1900 about the role of woman in educating children.

Who can do most for the elevation of the
moral standard of mankind? The woman,
the mother; it is at the breast of woman
that man receives his early nourishment.
The man learns there first, to feel, to think,
and to speak. And the earliest education of
all foreshadows the whole after life (p. 65).

In the same perspective, she underlined that every woman would be a teacher for their children. Women had to provide basic education which was useful for children's future. She emphasized the important role of women in education. She thought that the first education was from 'home'; mother. She also stated that the important factor in the civilization of people came from women. Kartini stated the letter to Stella Zeehandelaar on January 9, 1901.

In all ages the progress of woman has been an important factor in the civilization of a people. The intellectual education of the Javanese people can never progress if the woman is to be left behind" (p. 98)

\section{A Teacher Should Get the Basic Education of Teaching}

Based on Kartini's letter to Mevrouv Ovink-Soer in August, 1900, she agreed that to be a teacher she must be trained for the position. She should learn and study to pass the teacher examination.

But first I should have to be trained for the position; I should have to go to school for a year or so and study, to be able to pass the examination, because I would not undertake the work unless I were fitted for it (p. 93)

Kartini realized that to be a teacher, she should be educated first. She did not want to teach without any educational background. She had the dream to be a good teacher with the good basic education. Indeed, it was 
difficult to get education for girls. She started to realize that being an educated girl would be difficult because her father should spend extra money on her education. She expressed her feeling through the letter to Stella Zeenhandelaar on October 11, 1901.

I have already told you that we are not rich; though Father has a large income, at the sometime, his expenditures are great, so that we have only enough to live quietly and to give our boys (boys must be helped before everything) good educations. I also thought of the financial difficulties (p. 93).

She was going to study at home and to educate herself. She wrote her idea in the letter to Stella Zeenhandelaar on October 11, 1901.

I am going to study at home, and fit myself for the profession of teaching, just as well as one can be fitted by self-study, when it supported by a strong will, and perseverance (p. 129).

She got a big spirit to learn and read books to enrich her knowledge. So, she was struggling to get an education for the profession. She strongly believed that basic education was needed for the teacher; thereby, she was fitted for the professional. It was proven with what she did. She still educated herself by reading books at home. She proved that there was nothing impossible to grow and improve our knowledge.

\section{A Teacher Should Become the Example for Students}

Kartini gave the evidence through the letter to Stella Zeenhandelaar on October 11, 1901.

As a teacher, even of a little circle, there would be a direct influence exerted upon that little circle, which would in time, widen and spread out so that many would follow my example. I must go among the children as an elder sister, and be an example to them (p.122).

In this letter, she wanted to be an example as an elder sister who guided the students to do a right action toward the people around them. She showed that being a good example for students might bring a good effect on students' future. The example should be practiced in classes and daily life.

As what happened in Indonesia, Kartini was the one who was brave to break the custom and to show that people can be free and independent. She said her will through the letter to Stella Zeenhandelaar on October 11, 1901.

We want others to follow our footsteps. Our example then must be something compels respect and inspires emulation. We have not only our own wishes to consider, we must reckon with the prejudices and the character of the people whom we wish to enlighten (p. 124).

By teaching, she wished that she could be an example to awaken people and build a new perspective on education. For the reasons, it was a must for teachers to show the right example to the students. Hopefully, by doing this action, the student can also boost good examples among students. This concept is similar to what Ki Hajar Dewantara taught about Tut Wuri Handayani.

\section{A Teacher Should Teach Open- Mindedness, Love, Justice, and Rights}

Teachers should be aware of students' intentions and build an enjoyable and meaningful learning environment. She showed her passion for teaching through the letter to Stella Zeenhandelaar on October 11, 1901.

As a teacher of the domestic school, I should be with the children the whole day, even in the evening and at night I should not be wholly free, because the children would be under my care. Such a post would bring with it heavy responsibilities and duties ( $\mathrm{p}$. 122).

With this intention, Kartini tried to express her will that she wanted to be a passionate teacher and the best teacher for her students. Again, she pointed out some ideas if good teachers should be opened minded and teacher should teach love, justice, and rights 
too. In the same thoughts, Kartini expressed her concept through a letter to Stella Zeenhandelaar on August 15, 1902.

Javanese people have much need of schooling. And I, as a teacher, am to instruct the future mothers in practical knowledgeto teach them to understand love and justice and right conduct, as we have learned them from the Europeans (p. 65).

I should teach my children, boys and girls, to regard one another as equal human beings and give them always the same education; of course following the natural disposition of each (p. 83).

Those parts of the letter showed that Kartini had the concept that a good teacher had to understand love, justice, and rights so teachers could educate students about those important things.

Moreover, Kartini also tried to spread open-mindedness to students. She believed that being opened-minded made people realize that they lived together with other races. In this case, Kartini wrote her idea on how to be tolerant of others. She gave an example of how we should respect and understand the white race. She delivered the idea by writing the letter to Stella Zeenhandelaar on August 15, 1902;

I want to teach our people to know that white race as I know it in its finer, nobler aspects. They must learn of your nobleness, of your greatness, so that they will honor and love you. I want to do so much that sometimes I wish that I had a double pair of hands" (p. 180).

Also, Meadows (2006) emphasizes Dewey idea about being opened-minded. She stated that being opened-minded is important for teachers because it can make the individual and the democratic society grow and develop.

Based on the discussion, the root of Indonesian education that is seen from Kartini's perspective underlines the competencies of a teacher, including teachers' educational background, personalities, and values. Also, the teaching process should include moral, intellectual materials, and the condition or issue of a recent era, which is based on students' need.

\section{Conclusion}

Kartini had two important teaching principles. According to her, teaching moral and intellectual should have an equal position. This finding is a reflection for teachers that today's teaching process focuses more on students' competence. From the discussion on Kartini's teaching principle, teachers are invited to have both moral and intellectual aspects taught and learned equally together in the process of teaching.

The second teaching principle is that the material should be relatable to students' needs. Mulatsih (2018) also agreed with this principle, for example, by having poetry as a strategy to develop teaching skills. From this second teaching principle, our education system nowadays should adapt to the need of the young generation. Teaching methods can be more adaptable based on students' needs. The use of technological media for a better learning process is needed today.

Next, Kartini believed that basic education, being a good example, and having a value to be taught to construct a good teacher concept. In this case, a teacher can be seen as a good one when he/she has a passion for learning, relearning, and unlearning. The process of learning to gain professionalism is based on a teacher's desire. It is not gained from outside factors such as the government's certification. Kartini's idea may construct the professionalism of a teacher.

The second idea of a good teacher is that teachers should be an excellent example for students. Role modeling is the point of this concept. From this, Kartini's letters remind today's teachers for focusing more on teachers' behavior during the learning process than teachers' accomplishments for delivering the materials.

The last idea to be a good teacher is that teacher should teach opened-mindedness, love, justice, and rights. From this idea, today's teachers can ask themselves whether they 
already have important values to be taught to their students during their learning process in every class or not. The question is, 'do we only deliver all materials or more than that?'

\section{References}

ActionAid (2015). Promoting Rights in Schools: Providing Quality Public Education. Retrieved November 13, 2018 from http://www.actionaid.org/ sites/files/actionaid/prs_-_englishfinal_4_may_2011_2_0.pdf

Babicka-Wirkus, A. (2019). Children's Rights and Human Rights as a Key Condition for the Education of Transformative Teachers. In Kowalczuk-Walêdziak M., Korzeniecka-Bondar A., Danilewicz W., \& Lauwers G. (Eds.), Rethinking Teacher Education for the 21st Century: Trends, Challenges and New Directions (pp. 239252). Opladen; Berlin; Toronto: Verlag Barbara Budrich. doi:10.2307/ j.ctvpb3xhh.19

Bowen, G. A. (2009). Document analysis as a qualitative research method. Qualitative research journal, 9(2), 27.

Bullough Jr, R. V. (2011). Ethical and moral matters in teaching and teacher education. Teaching and Teacher Education, 27(1), 21-28.

Chickering, A. W., \& Ehrmann, S. C. (1996). Implementing the seven principles: Technology as lever. AAHE bulletin, 49, 36.

Driyarkara, N. (1980). Driyarkara tentang Pendidikan. Yogyakarta: Yayasan Kanisius.

Gatens, B. (2018, January 26). Teachers' Good Examples Have lifelong Impact. Retrieved from https://education.cuportland.edu/blog/curriculum-teachingstrategies/positive-example/
Guerin, W. L., Labor, E., Morgan, L., Raesman, J. C., \& Willingham, J. R. (2010). A Handbook of Critical Approaches to literature 6th ed. New York: Oxford University Press.

Jing, Y., Gao, S., \& Dong, Z. (2010, May). Analysis on the cultivation of the humanistic qualities of college students by social history education. In 2010 International Conference on Optics, Photonics and Energy Engineering (OPEE), 2, 99-102.

Johnson, J. (2019, May 18). The Importance of Good Personal Hygiene. Retrieved from http://www.hygieneexpert.co.uk/import ancegoodpersonalhygiene.html

Kartini, R. A. (1964). Letters of a Javanese princess. New York: Norton Library

Kirby, S. N., McCombs, J. S., Barney, H., \& Naftel, S. (2006). Reforming teacher education: something old, something new. Rand Corporation. Retrieved from http://www.jstor.org/stable/10.7249/m g506edu.10

Korthagen, F., Loughran, J., \& Russell, T. (2006). Developing fundamental principles for teacher education programs and practices. Teaching and teacher education, 22(8), 1020-1041.

Lane, A. (2016). Emancipation through Open Education: Rhetoric or Reality? In Blessinger P. \& Bliss T. (Eds.), Open Education: International Perspectives in Higher Education (pp. 31-50). Cambridge: Open Book. Retrieved from http://www.jstor.org/stable/j.ctt1sq5v9 n.7

McLeod, J. (2014). A peaceful pedagogy: Teaching human rights across the curriculum. Procedia-Social and Behavioral Sciences, 152(7), 1225-1232.

Meadows, E. (2006). Preparing teachers to be curious, open minded, and actively reflective: Dewey's ideas reconsidered.Action in Teacher Education, 28(2), 4-14. 
Mulatsih, M. I. (2018). Learning poetry as a strategy to develop teaching skill among students. International journal of Indonesian education and teaching (IJIET), 2(2), 120-128.

Natanael, T., \& Putranti, A. (2019). The Interpersonal Factors Affecting the Introduction to English Literature Lecturers' Politeness Strategy. Journal of Language and Literature, 19(1), 101-113.

Ornstein, A. C., Levine, D. U., Gutek, G. (201). Foundations of education. Belmont: Wadsworth.

Petty, G. (2009). Teaching Today: A Practical Guide (4th ed.). Cheltenham: Nelson Thornes Ltd.

Proctor, R. E. (1998). Defining the Humanities: How Rediscovering a Tradition Can Improve Our Schools: with a Curriculum for Today's Students. Indiana University Press.

Raufelder, D., Nitsche, L., Breitmeyer, S., Keßler, S., Herrmann, E., \& Regner, N. (2016). Students' perception of "good" and "bad" teachers-Results of a qualitative thematic analysis with German adolescents. International Journal of Educational Research, 75, 31-44.

Ryan, K. \& Bohlin, K.E. (1990). Building character in schools-practical ways to bring moral instruction to life. San Fransisco: Jossey-Bass A Wiley Imprint.

Sistalia, N. (2017). Raden Adjeng Kartini's dreams of marriage and education in the era of Dutch colonialism in Indonesia as seen in letters of a Javanese princess (Unpublished Undergraduate Thesis). Sanata Dharma University, Yogyakarta.

Setiawan, D. (2013). Peran pendidikan karakter dalam mengembangkan kecerdasan moral. Jurnal pendidikan karakter, 1.

Stooksberry, L. M., Schussler, D. L., \& Bercaw, L. A. (2009). Conceptualizing dispositions: Intellectual, cultural, and moral domains of teaching. Teachers and Teaching: theory and practice, 15(6), 719-736.

Sularto, S. (2016). Inspirasi kebangsaan dari ruang kelas. Jakarta: Penerbit Buku Kompas.

Sulisworo, D. (2016). The Contribution of the education system quality to improve the nation's competitiveness of Indonesia. Journal of Education and Learning, 10(2), 127-138.

Sundari, M. T. (2015). A study of R.A Kartini's conflict in letters of a Javanese princess translated by Agnes Louis Symmers. Tulungagung: Institut Agama Islam Negeri.

Tanjung, N. S., Adelina, P. D., Siahaan, M. K., Purba, E., \& Afriany, J. (2018). Sistem Pendukung Keputusan Pemilihan Guru Teladan Dengan Menggunakan Metode Composite Perfomance Index (CPI). JURIKOM (Jurnal Riset Komputer), 5(1), 13-18.

Tyson, L. (2011). Using critical theory: How to read and write about literature. London: Routledge.

UNICEF. (2018, October 1). Water, sanitation and hygiene. Retrieved September 10, 2019, from https://www.unicef.org/ indonesia/water-sanitation-and-hygiene 